\section{The panic virus}

A true story of medicine, science, and fear

Seth Mnookin

Simon and Schuster. New York, New York, USA. 2011.

448 pp. \$26.99. ISBN: 978-1-439-15864-7 (hardcover).

Reviewed by Max Wiznitzer

Case Western Reserve University, Rainbow Babies and Children's Hospital, Cleveland, Ohio, USA.

E-mail:mxw12@case.edu

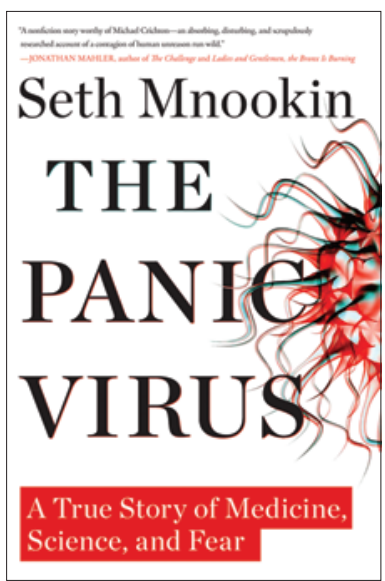

S ince the development of the first vaccine, controversy about their use has existed. At times, concerns have been justified; at others times, comments have reflected unwarranted claims. The facts about the most recent uproar are the core of The Panic Virus: A True Story of Medicine, Science, and Fear by Seth Mnookin. Mnookin unfolds the story of public worry about the claim of a relationship between vaccines and autism in a well written and easily understood book. Mnookin starts with a clinical description of a vaccine-preventable infection and then provides a history of vaccine use in the US, before addressing his thesis: the use of speculation and pseudoscience to promote the concept of the vaccine-autism relationship. He follows a timeline of key events and relates the apparent scientific manipulations and undisclosed conflicts of interest of Andrew Wakefield, the man who triggered the public panic about measles, mumps, and rubella vaccine by making unsupported assertions about its relationship to autism $(1,2)$. Combined with others' statements about the purported similarity between mercury poisoning and autism (3), these claims triggered a storm of controversy, escalated parental concerns, and decreased vaccination rates. Throughout his book, Mnookin inserts narratives of the consequences of failure to vaccinate, sometimes with fatal effect. The book culminates in the legal impact of these allegations, summarizing the proceedings in the US Court of Federal Claims Omnibus Autism Proceedings and the decision that there was a lack of evidence to support claims that the vaccine preservative thimerosal or MMR caused autism (4). These legal maneuvers continued and resulted in a US Supreme Court decision, confirming vaccine manufacturers' immunity from defective design claims (5).
This book's strength is its explanation of the human and societal factors that initiated and sustained the misperception that vaccines cause autism (6). Although at another time in history this might have been dismissed or ignored, modern technology allowed this idea to be easily proposed and disseminated and made it difficult for some individuals accessing information via electronic media to discern fact from speculation. In addition, limited societal exposure to preventable natural infections changed the perception of vaccine benefits and risks. When combined with an evolving mistrust of scientific and medical integrity, these factors elevated anecdote and personal opinion above proven research for some members of the public. The emotional impact of personal descriptions of children's purported changes after vaccination and the greater valuation of an education from the "University of Google" discounted attempts at a rational discussion of the issue's scientific merits. In addition, the increasing prevalence of autism spectrum disorders, public perception of no reason or cure for autism, concerns for environmental contaminants, and lack of an understanding of the scientific method resulted in mistaken conclusions that, for some, bordered on ideology or faith.

A major contributing and sustaining factor was the media. With the need for $24 / 7$ news, scientific information was relegated to the level of a brief sound bite. Easily understandable parental narratives often had more impact than complex research data. Furthermore, the media's desire to present a "balanced" story by giving equal weight to proven scientific fact and unproven hypotheses gave validity to speculation and introduced unwarranted doubt and concern in the minds of some who were seeking information.

Mnookin also focuses on those who presented the information. Opinions of celebrities and parents were accorded the same value as those of scientists and physicians. Yet, while proponents of the vaccine-causesautism claim and their supporters made effective use of the media, those with the scientific facts faced greater challenges in adequately communicating information to educate the public. Even as the scientific response has significantly improved, doubt has been established in the American psyche, which will require years to diminish (7).

The Panic Virus is highly recommended reading for those who want to understand the facts and myths surrounding the claims that vaccines cause autism and other developmental disorders. In a broader sense, it is a lesson about factors that produced this issue and need to be understood by the scientific community. Otherwise, we will be continually confronted by similar situations that, in the end, negatively impact public health and the greater public good.

1. Deer $B$. How the case against the MMR vaccine was fixed. BMJ. 2011;342:c5347.

2. Deer B. Secrets of the MMR scare. How the vaccine crisis was meant to make money. BMJ. 2011; 342:c5258

3. Bernard S, Enayati A, Redwood L, Roger H, Binstock T. Autism: a novel form of mercury poisoning. Med Hypotheses. 2001;56(4):462-471.

4. U.S. Courts of Federal Claims. Autism Decisions and Background Information. Web site. http://www.uscfc. uscourts.gov/node/5026. Accessed May 6, 2011.

5. Russell Bruesewitz, et al., petitioners vs. Wyeth LLC, Fka Wyeth, Inc., F Wyeth Laboratories, et al. Supreme Court of the United States Web site. http://www.supremecourt.gov/opinions/10pdf/ 09-152.pdf. Accessed May 6, 2011

6. Gross L. A broken trust: lessons from the vaccineautism wars. PLoS Biol. 2009;7(5):e1000114.

7. Freed GL, Clark SJ, Butchart AT, Singer DC, Davis MM. Parental vaccine safety concerns in 2009. Pediatrics. 2010;125(4):654-659. 